\title{
Development Opportunities and Challenges in
}

\author{
Northeast Asia : \\ The case of the Tumen River Project
}

\author{
Brian J. Sommers*, Lee Ki-Suk**, and \\ Lay James Gibson***
}

\begin{abstract}
Northeast Asia's potential for growth and development has always far exceeded its performance. Recent changes in the former Soviet Union together with sustained economic growth in Japan and South Korea suggest that Northeast Asia's economic role at a global scale will change substantially. The Tumen River Project illustrates both the opportunities available in Northeast Asia and the economic, historical, and political issues that are associated with development here. This paper examines the challenges faced by the region as it looks to its roles as an integrated industrial region and as a supplier of raw materials and manufactured goods to markets around the Sea of Japan and elsewhere.
\end{abstract}

\section{Introduction}

Northeast Asia has long maintained a potential for economic growth and prosperity that far exceeded any real growth in the area. Partly due to problems of history or of politics, Northeast Asia remained a hinterland both in Asia and the world. Today, however, the potential of Northeast Asia is beginning to translate into a promise for the future.

Northeast Asia is a huge region with enormous potential. Accounting for the economic interplay of China, North and South Korea, Mongolia, Japan, and Russia is a big task and one that is much too ambitious for this paper. As a result, this research focuses on a particular development project-The Tumen River Project. The Project is of substantial interest by itself. But perhaps equally important, it provides a focus for exploring the complex issues associated with the development potentials of a resource-rich and strategically located region that overlaps with six national entities that represent vastly different positions in the world's economic order (Table 1).

With the "new world order", the political realities that held back development in Northeast Asia are beginning to give way to cooperation and economic change. As countries in the region have sought to modernize and to develop, long-time adversaries have become partners in trade and development. Nowhere is this more evident than in the Tumen River Devolopment Project (See Map). This joint project would bring together one-time enemies in an economic development program that exemplifies the new international nature of regional development. The completion of the Tumen River Project would create a hub for transportation and trade at the eastern end of an overland transportation network linking Asia to production centers and markets in Europe. Proponents of the project envision the creation of a world trading center which will someday rival the likes of

* Central Connecticut State University, Department of Geography, New Britain, Connecticut 06050, U.S.A.

** Seoul National University, Department of Geography Education Seoul, 151 KOREA

*** The University of Arizona, Department of Geography, Tucson, Arizona 85721, U.S.A. 
Table 1 Selected Development Indicators

\begin{tabular}{|c|c|c|c|c|c|c|c|}
\hline \multirow{2}{*}{. } & \multirow[b]{2}{*}{$\begin{array}{c}\text { Population } \\
\text { (millions) } \\
\text { mid-1991 }\end{array}$} & \multirow[b]{2}{*}{$\begin{array}{c}\text { Area } \\
\text { (thousands } \\
\text { of square } \\
\text { kilometers) }\end{array}$} & \multirow{2}{*}{$\begin{array}{c}\text { GNP } \\
\text { (per } \\
\text { capita } \\
1991 \\
\text { dollars) }\end{array}$} & \multicolumn{4}{|c|}{ Distribution of 1991 GDP } \\
\hline & & & & Agriculture & $\begin{array}{c}\text { Industry } \\
\text { (except } \\
\text { Mfg) }\end{array}$ & $\begin{array}{c}\text { Manufac- } \\
\text { turing }\end{array}$ & Services \\
\hline China & 1,150 & 9,561 & 370 & 27 & 4 & 38 & 32 \\
\hline $\begin{array}{l}\text { Dem. Peoples } \\
\text { Republic of Korea } \\
\text { (North Korea) }\end{array}$ & 22 & 121 & $1,585^{*}$ & N/A & N/A & $\mathrm{N} / \mathrm{A}$ & N/A \\
\hline Japan & 124 & 378 & 26,930 & 3 & 17 & 25 & 56 \\
\hline Mongolia & -- & 1,567 & $1,585^{*}$ & N/A & N/A & N/A & N/A \\
\hline $\begin{array}{l}\text { Rep. of Korea } \\
\text { (South Korea) }\end{array}$ & 43 & 99 & 6,330 & 8 & 17 & 28 & 47 \\
\hline Russian Federation & 149 & 17,075 & 3,220 & 13 & {$[-\cdots--48$} & - & 39 \\
\hline
\end{tabular}

* Actual value estimated to be between $\$ 650$ and $\$ 2,520$.

Source: The World Bank 1993.

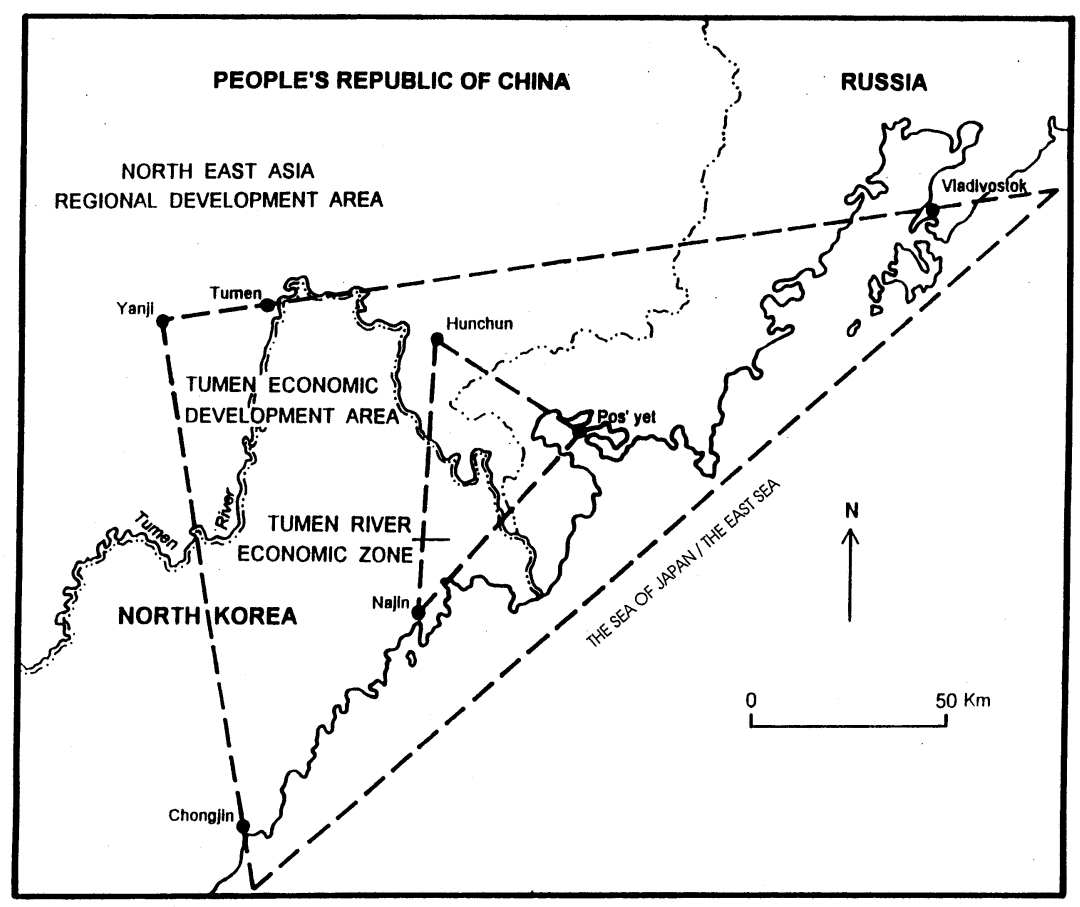

Fig. 1 Tumen River Delta Area 
Hong Kong and Rotterdam.

\section{Tumen River Project as Regional Development}

The Tumen River Project is a classic example of regional planning and development that has been adapted to post-cold war Asia. The project addresses the development of a region that has for many decades served as a hinterland. In doing so, the Tumen River Project has as its goal to advance the development of a region that encompasses countries which were, until recently, enemies in the cold war. It also brings in as partners, countries which still do not have normal relations with one another and who have on-going territorial disputes which threaten to undermine any development ventures which they might under-

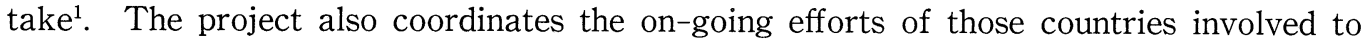
increase trade, and improve economic conditions in the region.

The Tumen River Project can be compared to other regional development and trade programs such as the European Community and the North American Free Trade Agreement. However, the unique circumstances prevent anything more than a rough comparison of these projects. Unlike the EC or NAFTA, the Tumen River Project brings together countries with vastly different levels of economic development, different economic and political systems, as well as countries whose primary trading partners are outside the region. On the other hand, the advantages of free trade and cooperative efforts in development that are felt in the EC or NAFTA countries are the ultimate goals of Tumen River development.

Another significant difference between the Tumen Project and other international development programs is in the strong complementarity of the economies of the partner countries. Despite apparent differences, the economies of the partner countries in the Tumen Project are far more complementary than those of the EC or NAFTA countries. While this will likely create some problems, it also creates an environment of strong growth potential and economic cooperation. The development of such a project from the ground up may also promote stronger regional ties by providing all of the partners with a stake in its success. This may ultimately create a better environement for development than in more one-sided projects.

\section{Project Context}

The Tumen region includes the Liaoning, Jilin, and Heilungjiang provinces of the People's Republic of China (China), the Sonbong region of the Democratic People's Republic of Korea (North Korea), the Primorskiy Kray in Russia, and Mongolia. ${ }^{2}$ The region has a long and complex history of political struggles and military conflict. ${ }^{3}$ The history of

\footnotetext{
${ }^{1}$ North and South Korea signed a non-aggression pact in December 1991. No formal relations exist between Japan and North Korea, or between South Korea and China. Ongoing territorial disputes over islands seized during World War II threaten to undermine political and economic relations between Russia and Japan (Kaye 1992a, 16).

${ }^{2}$ Although only in an economic sense, the Republic of Korea (South Korea), and Japan are also partners in the project. As a result, Japan and South Korea are considered as project partners for the purpose of this research.

${ }^{3}$ Prior to 1858 , the entire Tumen region was a part of greater China. In 1858, the Chinese were forced to turn over the entire coast of Siberia, including the Tumen River Delta to the Russians. In the late 19th and early 20th centuries, the Tumen region became the backdrop for both Russian and Japanese imperial interests and the scene of armed conflict between the two empires. The Tumen Region was also the stage for political struggles between Japan and China and was a stronghold of communism during and after World War II. In the decades that followed, Tumen was at the forefront of cold-war tensions between the U.S. and China, China and the Soviet Union, and between the two Koreas (Kaye 1992b, 19-20; Lee 1993, 20-21; Valencia 1991, 265).
} 
Table 2 Partner Country Strengths and Weaknesses

\begin{tabular}{|c|c|c|c|c|c|c|c|c|c|}
\hline Country & Capital & $\begin{array}{c}\text { Techno- } \\
\text { logy }\end{array}$ & $\begin{array}{c}\text { Manage- } \\
\text { ment }\end{array}$ & Labor & Energy & $\begin{array}{c}\text { Raw } \\
\text { Materials }\end{array}$ & $\begin{array}{c}\text { Agri- } \\
\text { culture }\end{array}$ & $\begin{array}{l}\text { Live- } \\
\text { stock }\end{array}$ & Industry \\
\hline China & W & W & W & $S$ & $S$ & $S$ & $S$ & $\mathrm{~N}$ & $\mathrm{~N}$ \\
\hline Japan & $S$ & $S$ & $S$ & W & W & W & W & W & $\mathrm{S}$ \\
\hline North Korea & W & W & $\mathrm{N}$ & $S$ & $\mathrm{~N}$ & S & W & W & $N$ \\
\hline South Korea & $S$ & $S$ & $S$ & W & W & W & $\mathrm{N}$ & $\mathrm{N}$ & $S$ \\
\hline Mongolia & W & W & $\mathrm{N}$ & $\mathrm{N}$ & $\mathrm{N}$ & $S$ & W & $S$ & $\mathrm{~N}$ \\
\hline Russia & W & $\mathrm{N}$ & W & W & $S$ & $S$ & W & $\mathrm{N}$ & W \\
\hline
\end{tabular}

KEY: $\mathrm{S}=$ Strength $\quad \mathrm{W}=$ Weakness $\quad \mathrm{N}=$ Neither or Not Applicable

Source: Geographical Institute, Northeast Normal University, Changchun, China and Kim 1992, 36-37.

conflicts in the region remains just below the surface of relations between the Tumen partner countries and is an important consideration in the politics of development throughout Northeast Asia.

Each of the partner countries in the Tumen River Development Project bring to the table a different set of resources that may be exploited as well as problems that need to be overcome. (Table 2 summarizes both the relative strengths and weaknesses of the project partner countries.) For Russia, China, North Korea, and Mongolia, the Tumen River Project brings together countries which have rich stores of natural resources but with chronic shortages of capital and/or technology for the exploitation of those resources. This shortage of capital also affects the infrastructure of the four countries, which is inadequate for current uses no less for future growth. For Russia and North Korea, the project also brings together two countries with strengths in heavy industry and military hardware production, but who are quickly losing markets for those products. Cooperation with the other project countries thus provides Russia and North Korea with an opportunity to retool their industries for consumer goods production (Chai 1993, 25 ; Economic Reporter 1994, 25-26, Jin 1993, 68 ; UNDP 1992, 6-1 ; UNDP 1991, 3-3 ; Valencia 1991, 267).

On the other end of the spectrum, the Tumen River Project also includes South Korea and Japan. Unlike the other countries that are involved in the project, Japan and Korea have abundant capital, modern infrastructure, and strengths in high technology production and management. Where these two countries have problems is in their need for natural resources and labor. Japan and Korea would also benefit from the Tumen Project in that it would provide the impetus for development along the Sea of Japan (Economic Reporter 1994, 25-26 ; Jin 1993, 68 ; Kaye 1992a, 16 ; UNDP 1992, 6-1; UNDP 1991 3-3 ; Valencia 1991, 267).

Due to the geographic extent and nature of the Tumen Project area, the benefits of the project would be widespread. The Tumen River Project will bring together countries with weaknesses and strengths which fit well with their partners in the project. It will also coordinate and combine the development efforts of Russia, China, and North Korea for the benefits of each and for the region as a whole (Stauffer 1992, 99 ; UNDP 1992, 6-1; UNDP 1991, $4-1$ to $4-2$ ). 


\section{Tumen Development Plan : Proposals}

The development activities of the partner countries and their proposals for the Tumen River Development Project are a reflection of the relative needs and/or aspirations of the partner countries. Although the classification of these proposed plans may provide for ease of discussion, it masks the intent of the various proposals. Likewise, the final plan provides a strong indication of the region-wide goals and strategies but little else. In order to more fully understand what each of the partner countries hopes to gain from the project, their approaches and proposals for Tumen River Project development need to be addressed. In doing so, it becomes possible to assess the intent and the ultimate goals of the countries participating in the project.

China-China wants to develop its three northern provinces. Chinese proposals for development are therefore aimed at improving China's export capabilities both to Japan via the Tuman River and to Russia and Europe via expanded rail systems. Chinese plans also call for the creation of international free trade zones within the Tumen development area. In particular, the Chinese are strong proponents of dredging the Tumen River ${ }^{4}$ and establishing port facilities for sea-going vessels on Chinese soil. The Chinese proposal also calls for Japanese and South Korean financing of the projects (Imai 1993, 15 ; Kim 1992, 39 ; Valencia 1991, 265). This proposal would provide China with greater access to foreign markets and build upon existing Chinese development projects in the region. It would also fuel the continued growth of the Hunchun-Fengtian region into a major economic power without relying totally on Chinese development funds (Kim 1992, 39; UNDP 1991, 3-1 to 3-3; Valencia 1991, 265).

North Korea-North Korea is interested in steering growth and investment to the SunbongNajin area. They stress that these ports do not freeze during the winter and would require little dredging (Kim 1992, 39). The acceptance of the North Korean model would direct port and transportation improvements into North Korea. The placement of the project's transport hubs in North Korea would then channel growth in manufacturing and trade there as well. This would result in economic gains through direct foreign economic and scientific assistance at a level which would benefit the entire country (Imai 1993, 16 ; UNDP 1991, 35 to 3-6).

Russia-The Russians are less interested in transportation and port improvement than in the transition of its heavy industry to consumer-oriented production. Their interests are therefore more in the trade and economic development aspects with an emphasis on including already established development and free trade zones within the geographic scope of the Tumen Project and in the creation of an environment conducive to outside investment. This stance may also be due to the fact that the Russians already have a system of ports and railroads which, although dated, could serve the needs of the project. Any changes in the transportation network could leave the entire Primorsky region and the port of Vladivostok isolated from project development (Imai 1993, 17 ; Kim 1992, 39; UNDP 1991,

\footnotetext{
${ }^{4}$ The Tumen River was a major transportation route connecting the cities of Fanchun, Hunchen, and Tumen to the Sea of Japan. Over time, the high sediment load has silted up the river. Frequent changes in the course of the river have also affected its navigability. The river also freezes during the winter limiting its use (Lee 1993, 16-18; Valencia 1991, 266). The dredging of the Tumen would make it navigable into China. However the dredging will require the movement of 12 million cubic meters of material to accommodate 200 ton ships or 30 million for 5,000 ton ships (Jin 1993, 78; Valencia 1991, 266). If put into effect, this element of the project would cost about $\$ 1.6$ billion (MAL 1992, 29; Valencia 1991, 266).
} 


\section{3-4 to $3-5){ }^{5}$}

Mongolia-While not putting forward their own development proposal, Mongolian officials have been active in pursuing their own national agendas in Tumen meetings. Mongolia's interest in the project is in its potential for improving transportation access for Mongolian products and in creating new development zones in order to open avenues for foreign investment capital. As a land-locked country, Mongolia is interested in opening new or improving the existing transport networks connecting the country to its major trading partners. With its shift to a market economy, Mongolia also needs foreign investment to spur growth. Mongolia's strategy therefore hinges on promoting any agenda items which would maximize these efferts (Imai 1993, 17 ; Kim 1992, 39, UNDP 1991, 3-3 to 3-4).

Japan and South Korea-Japan and South Korea are interested in Tumen for the promise of increased rail access to European markets and to natural resources. (An overland route would cut transport costs in half as compared to ship transport.) South Korea's interest in the project is also in fostering stronger ties with North Korea. As such, both Japan and South Korea are in favor of the project, although they are less interested than the other partner countries in exactly how the project's goals are implemented (Kim 1992, 40).

\section{Regional-Wide Goals}

The countries of the region have each embarked on individual programs of development. While these efforts may further the interests of the countries involved, it does not necessarily promote region-wide development and may actually expand regional economic disparities. This type of individual development is also wasteful in that it encourages the duplication of activities and national interests (UNDP 1991, 2-1). In some cases, the prevailing economic and political situations in the countries involved may also severely limit their abilities to generate outside interest, and capital, for such projects (Imai 1993, 18-19 ; Jin 1993, 78-80 ; Lee 1993, 10). Although each of the partners in the Tumen River Development Project have their own agendas, there are some goals to which all of the member countries can agree.

- Open up the flow of natural resources and high technology between the partner countries.

- Promote infrastructure development (transportation and communications) in the region.

- Improve the transportation of goods by opening a land-route for exports to Europe.

- Expand markets for the products of the partner countries.

- Improve economic conditions in the region.

- Foster stronger economic and political ties between the partner countries.

- To develop in a manner that is sensitive to the region's environment.

These broad goals for theTumen project reflect the combined interests of the Tumen partner countries and of the United Nations Development Programme. As indicated, however, each of the partners in the project have their own political and economic agendas in the region. While they may be down-played in the regional context, the final forrm of the Tumen River Development Plan may ultimately reflect those individual development agendas more than do these regional goals.

\footnotetext{
5 These concerns have prompted Russian opposition to the construction of a Northeast Asia Railway. This railroad would originate in Cita and pass through Mongolia and China to the port of Zarubino (Economic Reporter 1994, 26). While this proposal is undoubtedly popular with the Mongolian representatives, it would draw development away from centers on the Russian Trans-Siberian Railway.
} 


\section{The United Nations Development Programme Plan}

The United Nations Development Programme favors a model that places the development of the region under the control of a multi-national body which would include all of the Tumen River Developmemt Project partner nations. This plan has the advantage of promoting region-wide development while avoiding the problems of duplication and competition. The UNDP supported plan also creates a strong regional bloc that would be better able to coordinate and implement development projects. Furthermore, such an economic bloc would be better suited to the task of generating outside investment capital. The economic block would insulate potential investors in the project from some of the risks involved in doing business within the partner countries.

The participation of United Nations Development Programme in the project also provides benefits which would be lost if individual development strategies were followed. Direct sponsorship of the UNDP as well as its international supporters provides investment sources and means of political mediation which would not be possible within independent development programmes. UNDP support would also help to validate the Tumen Project in international circles. Finally, UNDP backing brings with it technical support and expertise in regional and internatinal development from UNDP and other United Nations sources (UNDP 1992, 2-9).

The direction of Tumen River Project activities will be through a joint management company. This company will consist of public and private sector representatives from all of the partner countries. China, North Korea, and Russia will then lease land to this company as shareholders in the venture. Despite the fact that each country would retain sovereignty over its lands, investment decisions, environmental concerns, as well as project management would be dealt with by the holding company (Chai 1993, 27 ; Yonhap 1992a, 44 ; Yonhap 1993b, 1 ; UNDP 1993, 43-45, 190-201). ${ }^{6}$ The joint management company would also be responsible for building and coordinating infrastructure projects. ${ }^{7}$

With respect to transportation investment, theTumen River Area Development Programme has a series of inter-connecting strategies. By improving air and sea-going transportation, the Tumen project will improve transportation within Northeast Asia (UNDP 1993, 80-82). By increasing the capacity of the existing road and rail networks, Tumen will allow inland areas to more efficiently export their products (UNDP 1993, 83). This will also spread the benefits of development beyond the boundaries of the Tumen River delta. Improving and/or re-routing the rail networks connecting Northeast Asia to Europe will open a land bridge for European trade (UNDP 1993, 83-84).

The benefits of the Tumen Project come with a very high price tag. Current estimates of project costs are in the neighborhood of $\$ 30$ billion dollars (UNDP 1991, 2-1, 2-5). It should be emphasized however that this is a conservative estimate. Many elements of the project may have costs that increase markedly as time goes by. Likewise, the actual sites selected for some activities may ultimately influence the costs of development. In addition,

\footnotetext{
${ }^{6}$ North Korea has stood against this part of the project as it allows outside forces to exercise decision-making power over indigenous authorities. In May of 1993, however, the North Koreans finally relented and agreed to lease some of their territory. This may indicate a new spirit of cooperation on the part of North Korea's political authorities. It may also indicate that the North Koreans have come to realize that they are unlikely to attract many investors on their own (Chai 1993, 27).

7 Governed activities would include the construction of seaports, railroads, roads, airports, power plants, and industrial parks. It would also include the development of 'new towns' with manufacturing, transportation, office, commercial activities, and housing linked to the Tumen Project (Imai 1993, 18).
} 
many of the projects that are currently on the drawing board are likely to stay there due to high costs, or because they do not necessarily further the region-wide goals of the project. ${ }^{8}$ The breakdown of these development costs are summarized in Table 3.

The cost of Tumen is well beyond the the current abilities of China, Mongolia, North Korea, and Russia. As a consequence, much of the financing will have to come from Tumen's financial partners, Japan and South Korea. The magnitude of the cost means that other potential sources of project funding will also need to be brought in. These include ;

1) private investment.

2) private investment supported by guarantee programs.

3) private-public investment partnerships.

4) private investment and public lending.

5) public lending.

Table 3 Major Project Expenditures

\begin{tabular}{|c|c|}
\hline Type of Expenditure & $\begin{array}{c}\text { Amount of Expenditure } \\
\text { (in } \mathbf{\$ 1 , 0 0 0 , 0 0 0 , 0 0 0 )}\end{array}$ \\
\hline Transportation Improvements ${ }^{9}$ & 11 \\
\hline Community Development Projects & 8 \\
\hline Power Production & 2 \\
\hline Telecommunication Projects & 1 \\
\hline Improvements in Water and Waste Systems & 2 \\
\hline Education & 1 \\
\hline Other & 5 \\
\hline TOTAL & 30 \\
\hline
\end{tabular}

Although the private investment option would provide for the greatest freedom of investment, the high degree of risk involved in investment within the region makes this an unlikely scenario. On the other hand, the political "strings" attached to foreign public lending make that a less than popular alternative. More than likely, investment in the projct will take the form of some type of public-private partnership supptrted by major world lending organizations (UNDP 1993, 207-212). ${ }^{10}$

Some elements of the Tumen River Development Project are already being put into action even if the plan itself is not. The prime example is in telecommunications improvements. This includes not only the expansion of the existing system but also the construction of new fiber optics networks to serve the advancing communications needs of the project partners. Such improvements are necessary due to the limited capabilities of the existing systems. In the Russian case, improvements in the telecommunications network are necessary as all communications into the region are currently routed through Moscow

${ }^{8}$ Although outside the political setting in which the term originated, may of these proposed projects may be thought of as a form of international "pork-barreling."

${ }^{9}$ This includes the costs for airports, railroads, roads, ocean ports, river ports, as well as terminal facilities for general cargo, specialized containers, breakbulk, Ro-Ro, coal, oil, grain, lumber, and passengers (UNDP 1991, 7-2 to 7-3).

${ }^{10}$ Foreign public funding is complicated by the fact that North Korea does not qualify for many sources of international finance (UNDP 1993, 213). 
(Yonhap 1993d, 18 ; Radio Vladivostok 1993, 1). While this type of activity would be included in Tumen development, the existing needs and market forces are enough to make such joint projects viable on their own.

\section{On-Going Developement Projects}

The Tumen River Project is one of many devlopment projects in the region. Each of the countries involved are active in many other projects that may or may not one day fall under the auspices of the Tumen River Project. In part, these projects are driven by local political concerns taking charge of their own economic fates. This development is also driven by market forces which are creating an economic environment conducive to regional growth. While not necessarily intended as such, these activities provide a fallback strategy in case the Tumen River Project falls through.

Russia-Although the development of Russia's Far East territories has gained momentum in recent years, many of the current efforts pre-date the fall of communism and of the Soviet Union. In the late 1980's free economic zones were established to promote development activities in the region. However, political upheavals and critical shortages of capital have slowed growth. As a consequece, the Russians have been involved in cooperative or joint projects. These projects center mostly on resource exploitation and utilize outside sources of capital and technology. Any payment for such assistance is taken out of project profits or is paid for in raw materials. The Russians obtain the capital and improvements in infrastructure that they need while providing their partners with sources of profit and natural resources. Many of these projects have involved capital and technological assistance from Japan and South Korea. As such, they are scaled-down models of the types of activities which would be part of the Tumen Project.

China-The Tumen River Project is on a par with projects in the Yangtze River Delta and in the Pudong area of Shanghai. In Northeastern China, however, there are numerous on -going projects designed to fuel development and foster stronger social, economic, and political ties with China's neighbors. Many of these projects are centered on Hunchun, a city reaping the benefits of improved ties to the Russian Far East (Postfactum 1992, 6-7 ; Tong-A Ilbo 1993, 25-26). ${ }^{11}$ On-going projects in the Hunchun area are designed to improve on its capacity for trade and economic growth with or without the Tumen-related development. $^{12}$

North Korea-North Korean ports serve as points of export for domestic as well as for Northern Chinese and Mongolian products. In recent years, North Korea has sought to increase the export capacities of seaports in Sonbong, Rajin, and Chungjin. In addition, current efforts at development in North Korea are also geared towards increasing foreign investment. ${ }^{13}$

${ }_{11}$ Hunchun has been made a special economic zone and an open city. This has provided tax incentives for development, much of which has been targeted for South Korean and Russian interests. This is due to the fact that Hunchun has a large ethnic Korean population and has port and rail linkages to Russia (Tong-A Ilbo 1993, 26).

${ }^{12}$ Hunchun projects include increasing coal resources and energy production, Yanji airport expansion, and telecommunications improvements. A new rail line is also being built which will allow Chinese exports to flow through the Russian port of Zarubino (Economic Reporter 1994, 26; Yonhap 1992b, 30 ; Jin 1993, 71-72).

${ }_{13}$ Along these lines, improvements have been made to the port facilities and to infrastructure connecting them to other points in North Korea (Yonhap 1992b, 28 ; Jin 1993, 74 ; North Korea Quarterly 1994, 23-33). A free economic/trade zone has also been established in the port cities of Rajin and Sonbong. This zone includes tax incentives, duty reductions, and streamlining of laws on trade and investment aimed at providing an environment conducive to outside investment (Yonhap 1992c, 28; Jin 1993, 74-75 ; North Korea Quarterly 1994, 23-33). 


\section{Project Benefits for Indivibual Partner Countries}

Even if it only satisfies regional goals, the Tumen River Project stands to benefit all involed. For China, Mongolia, North Korea, and Russia, the Tumen River Project presents opportunities for economic growth at both regional and national scales. It provides for improvements in infrastructure, especially in communications and transportation. The Tumen River Project may open other avenues for cooperative projects between partner countries and political entities outside the region. Participation in the Tumen River Project will also provide other potential benefits to these countries. For them, the Tumen River project will ;

China

Russia

Mongolia
-Provide direct access for sea-going vessels (If Tumen is dredged). -Continue development in Hunchun and Fangchun (Chai 1993, 26; Doian et al. 1993, 28 ; Economic Reporter 1994, 25 ; Kim 1992, 45 ; Valencia 1991, 267).

-Aid in resource development activities.

-Aid in converting Russia's heavy industry to more consumeroriented production

(Dorian et al. 1993, 28 ; Kim 1992, 45 ; Valencia 1991, 267-268).

-Increase the availability of hard currency.

-Help to ensure the country's economic survival (Chai 1993, 26 ;

Dorian et al. 1993, 27-28; Kim 1992, 45).

-Aid in natural resource development.

-Provide transportation access and markets for the country's agricultural products. (Dorian et al. 1993, 28 ; Kim 1992, 45).

South Korea and Japan will benefit from the Tumen Development Project in that is will provide them with access to labor, natural resources, and agricultural exports. It will also open markets for their products and provide an overland route for exports to Europe (Chai 1993, 26 ; Dorian et al. 1993, 28). This will, in turn, lower transportation costs and the time it takes for shipments to Europe (Chungang-Ilbo 1993, 10). In addition, the Tumen project will generate economic growth along the Sea of Japan and provide the impetus for development away from the traditional cores of Seoul and Tokyo (Yonhap 1992b, 31 ; Kaye 1992a, 17). For South Korea, Tumen may improve relations with North Korea and allow for the economic unification of Korean populations in the two Koreas as well as in China. It may also contribute to the political unification of the Koreas (Chai 1993, 26-27; Kim 1992, 40 ; Valencia 1991, 267).

\section{Potential Pitfalls}

Despite the prospects for success and the benefits to be realized by the partner countries, there is still a chance that the whole project could fall apart. This could occur should one of the primary players in the project, China, Japan, North Korea, South Korea, or Russia pull out. Although each stands to gain from the Tumen development, there are scenarios in which each could or would be willing to back out of the project. These scenarios are as follow ;

Russia-Russia currently has a monopoly on overland transport routes to Europe via the port of Vladivostok and the Trans-Siberian railroad. For the Russians, the benefits of far eastern development need to be weighed against the loss of control over land transport (Clifford 1992, 18). The potential for continued political upheaval and the unenviable consequences of political course changes to the far right or far left also present scenarios which could put the Tumen River Development Project in jeopardy (Kraznaya Zvezda 1993, 
14 ; Kim 1992, 43). ${ }^{14}$

China-China is economically better-off than many of its partners in the Tumen Project. It thus has an advantage in its business dealings with them. China would lose some of that advantage with the implementation of the Tumen project. There is also strong competition within China for development resources. The Tumen project could, as a result, lose out to other development projects, especially those along the Pacific Coast (Chai 1993, 28 ; Clifford 1992, 18).

North Korea-North Korea has a great deal to gain from the Tumen project. However, North Korean participation could be influenced by the degree of outside influence or 'foreign pollution' that is felt within is borders. The active pariticipation of South Korea and that country's military alliance with the United States also pose potential problems from the North Korean persective (Clifford 1992, 19). The repercussions of North Korea's stance on nuclear inspections also poses a potential threat to the implementation of the program (Chai 1993, 28 ; Kim 1992, 43).

South Korea and Japan-South Korea and Japan will be expected to provide much of the capital required for the project. This role is quite a risky one given the political and economic climates of the countries involved. In the recent past, Japanese and Kerean investors have risked and lost capital in failed development projects in the region. With the uncertain political climates and the financial risks involved there is always the possibility that one of these "bankers" for the project may back out (Chai 1993, 28 ; Dorian et al. 1993, 28-30 ; Korea Times 1993, 27-28). ${ }^{15}$

Other potential problems looming on the horizon include how a project such as Tumen is to be funded. In addition, difficulties involved in bringing together such diverse economies may also prove problematic. Finally, there are also political issues stemming from the region's checkered past lying just beneath the surface. These may threaten not only the ultimate success of the project, but also the mere existence of such a cooperative development effort.

\section{Arguments Against the Tumen Project}

While the Tumen Project may eventually fall apart due to any number of potential problems, there are arguments that it is not worth pursuing period. The Tumen River Project may be debated on a variety of points. First, Tumen may be debated on economic grounds. This includes questions over whether existing port facilities would be adequate for future growth (Chai 1993, 29-30 ; Valencia 1991, 268), and on whether new development is going to be significantly better than making improvements in the existing infrastructure (Chai 1993, 29 ; Kaye 1992a, 17 ; Valencia 1991, 268). Similarly, Tumen's economic viability can be debated with reference to specific elements of the project. This is especially true in the case of the plans proposed for the dredging of the Tumen River (Chai 1993, 29 ; Kaye 1992a, 17 ; Kim 1992, 39).

Another point on which the Tumen Project can be debated is its worth relative to the

${ }^{14}$ For its trading partners, investment in Russia is a risky business (Kyodo 1993d, 2). Russian projects have been jeopardized on a number of occasions by political crises (Kyodo 1993b ; Radiostantsiya Tikhiy 1993, 4 ; Yonhap 1993a, 27), by on-going border disputes, by the inability of the government or enterprises to make payments (Kyodo 1993a, 3 ; Izvestiya 1993, 28), and by Russian business practices which stress acquisition of devemopment funding over long-term business partnerships (Kyodo 1993d, 2). While these may not result in the Russian abandonment of Tumen, they definitely affect the approach of Russia's partners in their business dealings in Russia.

15 The Japanese are also very sensitive to the on-going border dispute with Russia over the Kuril Islands. Any escalation of this dispute could put in question Japan's participation in the entire Tumen Project. 
overall development of the partner countries. The question in this case is not whether the Tumen Project itself is economically viable, but whether it is worth taking development funds out of other projects to fund Tumen (Chai 1993, 29). For the Chinese and Russians this is an important question as Tumen is only one of many on-going development projects.

An extension of the debate over the importance of Tumen is whether regional growth is inevitable even without implementation of the project. In this case, the Tumen debate is whether the project is necessary for the type of development envisioned for the region or is development inevitable due to market forces (Kim 1992, 45). If development is inevitable, then why channel all of the development resources into the region?

\section{Prosects for Success}

The final point in the debate over Tumen is whether it is even possible given the extent of the political, economic, and financial challenges involved. Tumen is something that is new and untried. It is economic development in an environment of extreme risk and some will debate whether that risk is worth taking. However, where there are extreme risks there are often extreme rewards.

In spite of the political and financial hurdles that must be overcome, the Tumen project holds great economic promise for the partner countries. By bringing together countries with economic strengths and weaknesses that dovetail so closely with one another, the Tumen project provides potential benefits for all of the players involved. The Tumen River Development Project may also provide political benefits in lessening tensions in the region. It may also create stronger social and economic bonds between the countries of Northeast Asia. If indeed the project can live up to its billing of producting one of the world's largest economic blocks and of creating a Northeast Asian version of Rotterdam or Hong Kong, it would be hard to argue its importance in the growth of all Northeast Asia.

\section{BIBLIOGRAPHY}

Chai, Denise, "Boondoggle or Bonanza : The Tuman Project," Business Korea, August 1993, pp. 25-29.

Chungang Ilbo, "Article Views Tumen Project Status," May 12, 1993, pp. 9-10.

Clifford, M., Kaye, L., and L. do Rosario, "Trade and Trade-Offs: Potential Partners Weigh Benefits of Cooperation", Far Eastern Economic Review, January 16, 1992, pp. 18-19.

Dorian, J.P., Fridley, David, and Kristin Tressler, "Multilateral Resource Cooperation Among Northeast Asian Countries," Journal of Northeast Asian Studies, 12(1) 1993, pp. 3-34.

Economic Reporter, "Bright Prospects for Tumen River Delta," No. 2, 1994, pp. 25-26.

Holm, A., "Political Economy of the Tumen River Area Development Programme," Tumen River Area Development, United Nations Development Programme, 1992, pp. 86-98.

Imai, Satoshi, "Tumen River Area Special International Economic Zone," China Newsletter, May-June 1993, pp. 14-24.

Izvestiya, "South Korea Seen Unlikely to Accept Arms for Debt," September 1, 1993, p. 28.

Jin, K.S., "Tumen River Area Development Project and Inter-Korean Economic Cooperation," East Asian Review 5(2) 1993, pp. 65-86.

Kaye, L., "Hinterland of Hope : Regional Powers Have Ambitious Plans for Tumen Delta," Far Eastern Economic Review, 1992a, January 16, pp. 16-17.

Kaye, L., "Casualty of History: Progress Retarded by Political Turbulence," Far Eastern Economic Review, 1992b, January 16, pp. 19-20.

Kim, E., "Political Economy of the Tumen River Basin Development," Journal of Northeast Asian Studies, 11(2) 1992, pp. 35-48.

Korea Times, "Businessmen Note Investment Problems in Russia," June 4, 1993, pp. 27-28.

Krasnaya Zvezda, "Harm of PRC Economic Siege in Far East," September 28, 1993, p. 14. 
Kyodo, "80\% of Russian Far East Ventures Inactive," August 30, 1993a, p. 3.

Kyodo, "Tokyo-Moscow to Study Feasibility of Ferry Route." April 2, 1993b, pp. 22-23.

Kyodo, "DPRK Absent from U.N. Development Project Meeting," March 18, 1993c, p. 10.

Kyodo, "Russian Entrepreneur Seeks Foreign Investment," March 10, 1993d, pp. 2-3.

Lee, Ki-Suk, "Geographical Implications of the Tumen River Area Development," Presentation at the International Conference of Regional Science, October 1993.

$M A L$, "Tumen River Project Development Plan Detailed," February 27, 1992, pp. 29-34.

North Korea Quarterly, "Tumen River Development Program," Vol. 69/70, 1993, pp. 23-33.

Postfactum, "PRC to Form Free Economic Zones Along Border," April 6, 1992, pp. 6-7.

Radiostantsiya Tikhiy Okean, "Withdrawal of Japanese Finance Suspends Zarubino Port Project," May 3, 1993, p. 4.

Radio Vladivostok, "Internatinal Conference Discusses Tumen River Project," September 10, 1993, p. 1.

Stauffer, R., "Industrial Strategy for the Tumen River Economic Zone," Tumen River Area Development, United Nations Development Programme, 1992, pp. 99-119.

Tong-A Ilbo, "Hunchun Mayor Discusses Tumen Development," February 11, 1993, pp. 25-26.

United Nations Development Programme, Tumen River Area Development Programme, Beijing, China : United Nations Development Programme, 1993.

United Nations Development Programme, Tumen River Area Development Programme: Programme Management Committee First Meeting, Seoul, ROK: United Nations Development Programme, 1992.

United Nations Development Programme, Tumen River Area Development : Mission Report, Pyongyang, DPRK : United Nations Development Programme, 1991.

Valencia, Mark, "Economic Cooperation in Northeast Asia: The Proposed Tumen River Scheme," The Pacific Review, 4(3) 1991, pp. 263-271.

World Bank, World Development Report, Oxford, UK : Oxford University Press, 1993.

Yonhap, "Firms to Suspend Pursuit of Investment in Russia," September 28, 1993a, p. 27.

Yonhap, "Tumen River Project Talks Make 'Major Progress'," May 19, 1993b, p. 1.

Yonhap, "DPRK Absent from U.N. Conference on Tumen River," March 18, 1993c, pp. 23-24.

Yonhap, "DPRK Proposes Building Telecom Center for Tumen," February 4, 1993d, p. 18.

Yonhap, "ROK, DPRK, PRC, Russia Agree to Tumen River Holding Company," October 15, 1992a, p. 44.

Yonhap, "North Hopeful on ROK Investments," February 27, 1992b, p. 28.

Yonhap, "Tumen River Project Meeting Opens in Seoul," February 27, 1992c, pp. 27-28. 